\title{
PENGARUH BAURAN PEMASARAN TERHADAP KEPUTUSAN PEMBELIAN PADA TOKO BUKU KARISMA BALIKPAPAN
}

\author{
Finadella Yeriska Purnomo \\ Sasmoyo Dimas Radityo \\ STIE Madani Balikpapan \\ Email: sdimasr@gmail.com
}

\begin{abstract}
ABSTRAK
Tujuan penelitian ini adalah untuk mengetahui dan menganalisis pengaruh baik secara simultan maupun parsial faktor-faktor bauran pemasaran yang terdiri dari produk (X1), harga (X2), lokasi (X3), dan promosi (X4) terhadap keputusan pembelian (Y) pada Toko Buku Karisma Balikpapan serta untuk mengetahui variabel bauran pemasaran yang berpengaruh paling dominan terhadap keputusan pembelian. Metode penelitian yang digunakan yaitu kuantitatif deskriptif dengan sumber data primer. Teknik pengumpulan data dengan menggunakan kuesioner, jumlah responden yang digunakan sebanyak 115 responden dan dianalisis menggunakan SPSS versi 20.0. Metode analisis yang digunakan yaitu analisis regresi linier berganda. Berdasarkan hasil uji $F$ menunjukkan adanya pengaruh secara signifikan antara variabel produk, harga, lokasi, dan promosi terhadap keputusan pembelian pada Toko Buku Karisma Balikpapan. Sedangkan, hasil uji t menunjukkan bahwa hanya variabel produk, harga, dan promosi berpengaruh signifikan terhadap keputusan pembelian, sedangkan variabel lokasi tidak berpengaruh signifikan terhadap keputusan pembelian pada Toko Buku Karisma Balikpapan.
\end{abstract}

Kata kunci : Bauran Pemasaran, Produk, Harga, Lokasi, Promosi, Keputusan Pembelian

\section{PENDAHULUAN}

Perkembangan usaha toko buku pada saat ini sangat pesat, sehingga persaingan usaha toko buku sangat kompetitif dan masing-masing toko menawarkan harga yang bersaing, pelayanan yang memuaskan, kualitas dan kelengkapan produk, desain dan tata letak toko serta keamanan dan kenyamanan saat berbelanja. Konsumen dihadapkan pada berbagai pilihan atau alternatif toko buku, sehingga perusahaan dituntut untuk mengikuti perkembangan pasar dan mengetahui selera konsumen. Terlebih, adanya teknologi yang semakin canggih membuat konsumen juga semakin pandai untuk memastikan suatu produk tersebut baik atau tidak sebelum mereka membelinya. 
Perkembangan toko buku yang ada di kota Balikpapan khususnya, juga sangat pesat. Semakin banyaknya toko buku yang bermunculan membuat persaingan perusahaan toko buku yang ada di Balikpapan semakin ketat dan kompetitif. Perusahaan-perusahaan tersebut bahkan tidak hanya menawarkan buku, tetapi juga produk-produk lainnya seperti alat tulis dan perlengkapan kantor serta kebutuhan sekolah. Perusahaan toko buku mencoba menarik perhatian konsumen dengan menjual produk lainnya selain buku, karena diketahui bahwa pada saat ini minat baca masyarakat semakin menurun dan juga adanya kemudahan untuk membaca buku secara online. Hal ini dibuktikan dengan adanya pernyataan dari Wakil Ketua Bidang Humas, Riset, dan Informasi Ikatan Penerbit Indonesia (IKAPI) Pusat, Indra Laksana mengatakan bahwa penjualan buku mengalami penurunan, salah satunya disebabkan interaksi masyarakat Indonesia yang kuat dengan internet. IKAPI melihat minat baca meningkat, tetapi interaksinya sudah multimedia bukan hanya buku. Ada peningkatan minat baca, tetapi berbasis daring yaitu materi-materi yang ada pada buku saat ini lebih mudah ditemukan di internet. Dengan kata kunci di mesin pencari, informasi yang diperlukan sudah terpampang di layar komputer atau perangkat genggam tanpa perlu buku dan membolak-balikkan halamannya. Karena itu, bila dilihat dari sisi penerbit konvensional, volume penerbitan dan jumlah toko buku mengalami penurunan (republika.co.id, 2017).

Toko Buku Karisma Balikpapan berlokasi di lantai satu Plaza Rapak, Jalan Soekarno Hatta, Kelurahan Muara Rapak, Kecamatan Balikpapan Utara, Kalimantan Timur, kode pos 76124 dan merupakan salah satu toko buku yang ada di Balikpapan yang berdiri pada tahun 2003. Toko Buku Karisma merupakan sebuah usaha ritel yang menerima buku-buku dari penerbit atau distributor dan produk lainnya untuk dijual kembali. Dalam usahanya Toko Buku Karisma Balikpapan menjual berbagai macam buku dengan klasifikasi dan judul buku yang beragam. Selain itu, Toko Buku Karisma juga menyediakan produk non buku seperti alat tulis dan perlengkapan kantor serta kebutuhan sekolah. Namun, seiring dengan perkembangan zaman dan persaingan yang semakin ketat Toko Buku Karisma Balikpapan harus membuat inovasi baru dan menarik agar dapat bersaing dengan toko buku lainnya.

Berdasarkan data penjualan Toko Buku Karisma Balikpapan pada tahun 2014 berjumlah 14.930, tahun 2015 berjumlah 14.139, tahun 2016 berjumlah 13.668, tahun 2017 berjumlah 12.882, tahun 2018 berjumlah 12.245, dan tahun 2019 berjumlah 11.428, maka penjualan pada Toko Buku Karisma Balikpapan mengalami penurunan dari tahun ke tahun. Pada tahun 2015 Toko Buku Karisma mengalami penurunan sebesar 791, pada tahun 2016 sebesar 471, pada tahun 2017 sebesar 786, pada tahun 2018 sebesar 637, dan pada tahun 2019 sebesar 817. 
Hal ini menunjukkan bahwa Toko Buku Karisma Balikpapan mengalami permasalahan dalam memasarkan produknya.

Dari hasil observasi di lapangan peneliti melihat koleksi produk pada Toko Buku Karisma Balikpapan mulai dari buku, alat tulis dan perlengkapan kantor serta kebutuhan sekolah beragam, tetapi kurang lengkap dan jarang diperbarui, desain dan fitur dari produk yang tersedia juga standar seperti pada umumnya, sehingga disinyalir hal tersebut yang menyebabkan konsumen beralih ke toko buku lain. Dari banyak faktor yang mempengaruhi konsumen tidak melakukan pembelian di Toko Buku Karisma Balikpapan, peneliti mengambil beberapa kesimpulan diantaranya, karena produk di toko buku lain lebih berkualitas, beragam, dan up to date, harga di toko buku lain sesuai dengan produk yang ditawarkan, sedangkan di Toko Buku Karisma Balikpapan harga produk khususnya buku lebih murah dan kualitas buku yang ditawarkan memang lebih rendah dibandingkan dengan toko buku lainnya, tempat/lokasi yang termasuk di dalamnya suasana di ruangan toko yang lebih nyaman dibandingkan dengan Toko Buku Karisma Balikpapan, dan promosi di toko buku lain lebih menarik, sedangkan di Toko Buku Karisma Balikpapan tidak lagi melakukan pengenalan produknya lewat event-event ataupun memberikan diskon.

Berdasarkan uraian permasalahan latar belakang di atas, peneliti tertarik untuk mengetahui apakah bauran pemasaran (produk, harga, tempat, dan promosi) dapat berpengaruh terhadap keputusan pembelian konsumen di Toko Buku Karisma Balikpapan dengan mengambil judul penelitian "Pengaruh Bauran Pemasaran terhadap Keputusan Pembelian pada Toko Buku Karisma Balikpapan".

\section{KERANGKA TEORI}

\section{a. Keputusan Pembelian}

Menurut Schiffman dan Kanuk dalam Marendra (2018:38) keputusan pembelian adalah pemilihan dari dua atau lebih alternatif pilihan keputusan pembelian, artinya bahwa seseorang dapat membuat keputusan, harus tersedia beberapa alternatif pilihan.

Menurut Prasetya (2015:48) indikator variabel keputusan pembelian dalam penelitian ini adalah:
a. Harga yang ditawarkan terjangkau.
b. Produk-produk yang lengkap.
c. Penawaran yang diberikan menarik.
d. Pelayanan yang cepat dan memuaskan. 
e. Fasilitas fisik yang aman dan nyaman.

\section{b. Bauran Pemasaran}

Menurut Kotler (2008:23) bauran pemasaran (marketing mix) didefinisikan sebagai perangkat alat pemasaran yang digunakan perusahaan untuk mengejar tujuan pemasarannya. Keputusan bauran pemasaran harus dibuat untuk memengaruhi saluran dagang dan juga konsumen akhir.

\section{c. Produk}

Menurut Alma (2013:139) produk ialah seperangkat atribut baik berwujud maupun tidak berwujud, termasuk di dalamnya masalah warna, harga, nama baik pabrik, nama baik toko yang menjual (pengecer), dan pelayanan baik serta pelayanan pengecer yang diterima oleh pembeli guna memuaskan keinginannya.

Adapun indikator yang digunakan dalam variabel produk (Prasetya, 2015:46) yaitu:

a. Kelengkapan produk atau keragaman produk yang ditawarkan.

b. Produk-produk yang ditawarkan berkualitas baik.

c. Selalu memberikan informasi tentang produk-produk baru.

d. Jaminan atau ganti rugi apabila produk tidak berfungsi sebagaimana diharapkan.

\section{d. Harga}

Menurut Deliyanti Oentoro dalam Sudaryono (2016:216) harga (price) adalah suatu nilai tukar yang bisa disamakan dengan uang atau barang lain untuk manfaat yang diperoleh dari suatu barang atau jasa bagi seorang atau kelompok pada waktu tertentu dan tempat tertentu.

Menurut Prasetya (2015:45-46) indikator variabel harga dalam penelitian ini adalah:

a. Keterjangkauan harga barang-barang yang ditawarkan.

b. Harga barang-barang yang ditawarkan sesuai dengan kualitas barang.

c. Harga barang-barang yang ditawarkan bersaing dengan pesaing lain.

d. Potongan harga atau diskon yang diberikan.

\section{e. Lokasi}

Menurut Tjiptono (2015:379) distribusi berkenaan dengan aktivitas pemasaran yang menyalurkan barang dan jasa dari produsen ke konsumen sedemikian rupa, sehingga 
konsumen dapat menggunakannya sesuai dengan keinginannya (jenis, jumlah, harga, tempat, dan saat dibutuhkan).

Menurut Malasari (2017:39) indikator variabel lokasi dalam penelitian ini adalah:

a. Lalu lintas kendaraan.

b. Fasilitas parkir.

c. Transportasi umum.

d. Komposisi toko.

e. Letak berdirinya toko.

\section{f. Promosi}

Menurut Hasan (2014:603) promosi merupakan fungsi pemasaran yang fokus untuk mengkomunikasikan program-program pemasaran secara persuasif kepada target pelanggan atau calon untuk mendorong terciptanya transaksi pertukaran antara perusahaan dan pelanggan.

Menurut Sangadji dan Sopiah (2013:18-19) indikator variabel promosi dalam penelitian ini adalah:

a. Periklanan.

b. Penjualan Perseorangan.

c. Promosi Penjualan.

d. Publisitas.

\section{METODE PENELITIAN}

\section{a. Jenis Penelitian}

Jenis penelitian yang digunakan adalah kuantitatif deskriptif. Menurut Sugiyono (2014:13) metode penelitian kuantitatif dapat diartikan sebagai metode penelitian yang berlandaskan pada filsafat positivisme, digunakan untuk meneliti pada populasi atau sampel tertentu, teknik pengambilan sampel pada umumnya dilakukan secara random, pengumpulan data menggunakan instrumen penelitian, analisis data bersifat kuantitatif/statistik dengan tujuan untuk menguji hipotesis yang telah diterapkan. Menurut Sugiyono (2014:53-54) rumusan deskriptif adalah rumusan masalah yang berkenaan dengan pertanyaan terhadap keberadaan variabel mandiri, baik hanya pada satu variabel atau lebih (variabel mandiri adalah variabel yang berdiri sendiri, bukan variabel 
independen, karena kalau variabel independen selalu dipasangkan dengan variabel dependen).

\section{b. Sumber Data}

Dalam penelitian ini, data yang digunakan adalah data primer. Menurut Sugiyono (2014:402) sumber primer adalah sumber data yang langsung memberikan data kepada pengumpul data.

\section{c. Teknik Pengumpulan Data}

Metode pengumpulan data yang digunakan dalam penelitian ini yaitu kuesioner. Kuesioner dapat berupa pertanyaan/pernyataan tertutup atau terbuka, dapat diberikan kepada responden secara langsung atau dikirim melalui pos atau internet. Dalam penelitian ini, metode pengumpulan data yang digunakan yaitu kuesioner tertutup dengan pengukuran skala likert.

\section{d. Populasi dan Sampel}

Populasi yang digunakan dalam penelitian ini adalah para pengunjung/konsumen yang pernah melakukan pembelian di Toko Buku Karisma Balikpapan bulan Januari 2020 berjumlah 160 orang. Teknik pengambilan sampel yang digunakan adalah nonprobability sampling. Metode pengambilan sampel yang digunakan adalah purposive sampling yaitu teknik penentuan sampel dengan pertimbangan tertentu (Sugiyono, 2014:122). Sampel yang diambil dalam penelitian ini memiliki kriteria yaitu responden berusia minimal 15 tahun, dengan asumsi pada usia tersebut responden sudah cukup dewasa, sehingga dapat memahami maksud dari kuesioner yang diberikan dan pernah melakukan pembelian di Toko Buku Karisma Balikpapan minimal satu kali. Jumlah sampel ditentukan dengan rumus Slovin yang dikemukakan oleh Umar (2013:78) dengan perhitungan sebagai berikut:

$$
\begin{aligned}
& \mathrm{n}=\frac{\mathrm{N}}{1+\mathrm{Ne}^{2}} \\
& \mathrm{n}=\frac{160}{1+160(0,05)^{2}} \\
& \mathrm{n}=\frac{160}{1+160(0,0025)}
\end{aligned}
$$




$$
\begin{aligned}
& \mathrm{n}=\frac{160}{1+0,4} \\
& \mathrm{n}=\frac{160}{1,4} \\
& \mathrm{n}=114,285 \text { dibulatkan menjadi } 115
\end{aligned}
$$

\section{e. Metode Analisis}

Metode analisis data yang digunakan pada penelitian ini mengacu pada penelitian terdahulu yang diataranya yaitu, uji validitas, uji reliabilitas. Untuk mengetahui pengaruh variabel independen terhadap variabel dependen digunakan uji regresi linier berganda, uji koefisien korelasi $(\mathrm{R})$, uji koefisien determinasi $\left(\mathrm{R}^{2}\right)$, uji F (uji simultan), dan uji t (uji parsial).

\section{HASIL DAN PEMBAHASAN}

Hasil penelitian dan pembahasan merupakan penjelasan dari hasil pengujian data primer variabel dependen dan independen dari penyebaran kuesioner yang berasal konsumen Toko Buku Karisma Balikpapan. Data tersebut dianalisis dengan menggunakan program SPSS 20.0. Hasil pengujian hipotesis dijelaskan sebagai berikut:

\section{a. Hasil Uji Validitas}

\begin{tabular}{|c|c|c|c|c|c|}
\hline No & Variabel & Item & $\mathbf{r}_{\text {tabel }}$ & rhitung & Ket \\
\hline \multirow{5}{*}{1} & \multirow{5}{*}{$\begin{array}{c}\text { Produk } \\
\text { (X1) }\end{array}$} & $\mathrm{X} 1.1$ & \multirow{5}{*}{0,1832} & 0,799 & Valid \\
\hline & & $\mathrm{X} 1.2$ & & 0,816 & Valid \\
\hline & & $\mathrm{X} 1.3$ & & 0,863 & Valid \\
\hline & & X1.4 & & 0,748 & Valid \\
\hline & & X1.Total & & 1,000 & Valid \\
\hline \multirow{3}{*}{2} & \multirow{3}{*}{$\begin{array}{c}\text { Harga } \\
(\mathrm{X} 2)\end{array}$} & $\mathrm{X} 2.1$ & \multirow{3}{*}{0,1832} & 0,806 & Valid \\
\hline & & $\mathrm{X} 2.2$ & & 0,819 & Valid \\
\hline & & $\mathrm{X} 2.3$ & & 0,792 & Valid \\
\hline
\end{tabular}

Tabel 1

Hasil Uji Validitas 


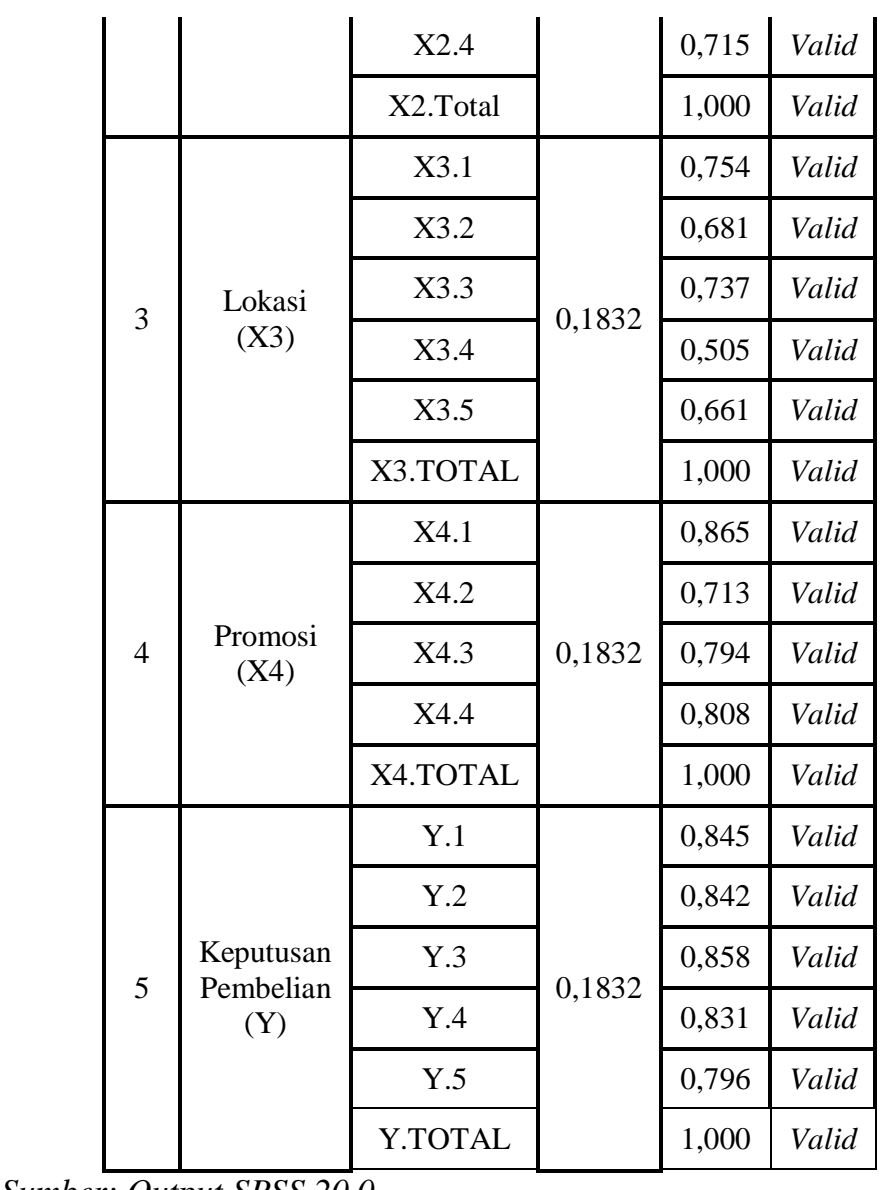

Sumber: Output SPSS 20.0

Berdasarkan tabel di atas, maka dapat disimpulkan seluruh item pernyataan tersebut valid karena nilai $r_{\text {hitung }}$ pada masing-masing item pernyataan lebih besar dari $r_{\text {tabel }}$ yaitu 0,1832 sehingga layak dianalisis dalam penelitian.

\section{b. Hasil Uji Reliabilitas}

Tabel 2

Hasil Uji Reliabilitas

\begin{tabular}{|c|c|c|c|}
\hline No & Variabel & $\begin{array}{c}\text { Cronbach } \\
\text { Alpha }\end{array}$ & Ket \\
\hline 1 & $\begin{array}{c}\text { Produk } \\
(\mathrm{X} 1)\end{array}$ & 0,818 & Reliabel \\
\hline 2 & $\begin{array}{c}\text { Harga } \\
\text { (X2) }\end{array}$ & 0,809 & Reliabel \\
\hline 3 & $\begin{array}{c}\text { Lokasi } \\
\text { (X3) }\end{array}$ & 0,758 & Reliabel \\
\hline 4 & $\begin{array}{c}\text { Promosi } \\
(\mathrm{X} 4)\end{array}$ & 0,814 & Reliabel \\
\hline
\end{tabular}

Sumber: Output SPSS 20.0 
Berdasarkan tabel 2 dapat diketahui bahwa nilai Cronbach Alpha pada masing-masing variabel lebih besar dari 0,60, artinya instrumen penelitian yang digunakan memenuhi syarat reliabilitas sehingga dapat dipercaya atau dapat diandalkan dalam penelitian ini.

\section{c. Analisis Regresi Linier Berganda}

Tabel 3

\section{Hasil Uji Regresi Linier Berganda}

\begin{tabular}{|l|l|r|}
\hline \multicolumn{2}{|c|}{ Coefficients $^{\text {a }}$} \\
\hline \multirow{2}{*}{ Model } & $\begin{array}{l}\text { Unstandardized } \\
\text { Coefficients }\end{array}$ \\
\cline { 2 - 3 } \multicolumn{1}{|c|}{} & B \\
\hline \multirow{3}{*}{1} & (Constant) & .714 \\
\cline { 2 - 3 } & PRODUK & .284 \\
\cline { 2 - 3 } & HARGA & .436 \\
\cline { 2 - 3 } & LOKASI & .050 \\
\cline { 2 - 3 } & PROMOSI \\
\hline \multicolumn{2}{|l}{$\begin{array}{l}\text { a. Dependent Variable: } \\
\text { KEPUTUSAN PEMBELIAN }\end{array}$} \\
\hline
\end{tabular}

Sumber: Output SPSS 20.0

Berdasarkan tabel di atas dapat diketahui persamaan regresi linier berganda sebagai berikut:

$Y=0,714+0,284 X_{1}+0,436 X_{2}+0,050 X_{3}+0,366 X_{4}$

\section{d. Hasil Uji Koefisien Korelasi (R)}

Tabel 4

Hasil Uji Koefisien Korelasi (R)

\begin{tabular}{|c|c|c|}
\hline \multicolumn{3}{|c|}{ Model Summary ${ }^{b}$} \\
\hline Model & $\mathrm{R}$ & Adjusted R Square \\
\hline 1 & $.724^{a}$ & .506 \\
\hline \multicolumn{3}{|c|}{$\begin{array}{l}\text { a. Predictors: (Constant), PROMOSI, } \\
\text { LOKASI, HARGA, PRODUK }\end{array}$} \\
\hline \multicolumn{3}{|c|}{$\begin{array}{l}\text { b. Dependent Variable: KEPUTUSAN } \\
\text { PEMBELIAN }\end{array}$} \\
\hline
\end{tabular}

Sumber: Output SPSS 20.0 
Berdasarkan tabel di atas, nilai koefisien korelasi (R) antara variabel independen dengan variabel dependen diperoleh sebesar 0,724. Apabila dilihat dari nilai interval koefisien korelasi berada di level 0,60 - 0,799, sehingga dapat disimpulkan terdapat hubungan tingkat korelasi yang kuat antara variabel produk $\left(\mathrm{X}_{1}\right)$, harga $\left(\mathrm{X}_{2}\right)$, lokasi $\left(\mathrm{X}_{3}\right)$, dan promosi $\left(\mathrm{X}_{4}\right)$ terhadap keputusan pembelian (Y).

\section{e. Hasil Uji Koefisien Determinasi $\left(\mathbf{R}^{2}\right)$}

Tabel 5

Hasil Uji Koefisien Determinasi $\left(\mathbf{R}^{2}\right)$

\begin{tabular}{|c|c|c|}
\hline \multicolumn{3}{|c|}{ Model Summary } \\
\hline Model & $\mathrm{R}$ & $\begin{array}{l}\text { Adjusted R } \\
\text { Square }\end{array}$ \\
\hline 1 & $.724^{a}$ & .506 \\
\hline \multicolumn{3}{|c|}{$\begin{array}{l}\text { a. Predictors: (Constant), } \\
\text { PROMOSI, LOKASI, HARGA, } \\
\text { PRODUK }\end{array}$} \\
\hline \multicolumn{3}{|c|}{$\begin{array}{l}\text { b. Dependent Variable: } \\
\text { KEPUTUSAN PEMBELIAN }\end{array}$} \\
\hline
\end{tabular}

Berdasarkan tabel di atas, dapat diketahui bahwa nilai koefisien determinasi/Adjusted $R$ Square menunjukkan angka 0,506 artinya sebesar 50,6\% dari variabel keputusan pembelian $(\mathrm{Y})$ ditentukan oleh variabel produk $\left(\mathrm{X}_{1}\right)$, harga $\left(\mathrm{X}_{2}\right)$, lokasi $\left(\mathrm{X}_{3}\right)$, dan promosi $\left(\mathrm{X}_{4}\right)$. Sedangkan sisanya sebesar 49,4\% (100\% - 50,6\%) disebabkan oleh faktor-faktor lain yang tidak diketahui.

\section{d. Pengujian Hipotesis}

\section{Uji Simultan/Uji F}

Tabel 6

Hasil Uji Simultan/Uji F

\begin{tabular}{|c|c|c|c|}
\hline \multicolumn{4}{|c|}{ ANOVAa $^{a}$} \\
\hline \multicolumn{2}{|c|}{ Model } & $\mathrm{F}$ & Sig. \\
\hline \multirow{3}{*}{1} & Regression & 30.208 & $.000^{b}$ \\
\hline & Residual & & \\
\hline & Total & & \\
\hline \multicolumn{4}{|c|}{$\begin{array}{l}\text { a. Dependent Variable: } \\
\text { KEPUTUSAN PEMBELIAN }\end{array}$} \\
\hline \multicolumn{4}{|c|}{$\begin{array}{l}\text { b. Predictors: (Constant), PROMOSI, } \\
\text { LOKASI, HARGA, PRODUK }\end{array}$} \\
\hline
\end{tabular}


Berdasarkan perhitungan dan analisis data diperoleh hasil $F_{\text {hitung }}>F_{\text {tabel }}(30,208>$ 2,454213) dan nilai Sig. $(0,000)<0,05$, maka Ho ditolak dan Ha diterima. Artinya terdapat pengaruh signifikan secara simultan antara variabel independen yaitu variabel produk $\left(\mathrm{X}_{1}\right)$, harga $\left(\mathrm{X}_{2}\right)$, lokasi $\left(\mathrm{X}_{3}\right)$, dan promosi $\left(\mathrm{X}_{4}\right)$ terhadap variabel dependen yaitu keputusan pembelian (Y) pada Toko Buku Karisma Balikpapan.

\section{Uji Parsial/Uji t}

\section{Tabel 11}

\begin{tabular}{|c|c|c|c|}
\hline \multicolumn{4}{|c|}{ Hasil Uji Parsial/Uji t } \\
\hline \multicolumn{4}{|c|}{ Coefficients $^{a}$} \\
\hline \multicolumn{2}{|c|}{ Model } & $\mathrm{T}$ & Sig. \\
\hline \multirow{5}{*}{1} & (Constant) & .426 & .671 \\
\hline & PRODUK & 2.461 & .015 \\
\hline & HARGA & 3.215 & .002 \\
\hline & LOKASI & .518 & .606 \\
\hline & PROMOSI & 3.027 & .003 \\
\hline \multicolumn{4}{|c|}{$\begin{array}{l}\text { a. Dependent Variable: KEPUTUSAN } \\
\text { PEMBELIAN }\end{array}$} \\
\hline
\end{tabular}

Berdasarkan hasil penelitian ini untuk variabel produk diperoleh nilai $t_{\text {hitung }}>t_{\text {tabel }}($ $2,461>1,98177)$ dan nilai Sig. $(0,015)<0,05$, maka Ho ditolak dan Ha diterima yang berarti H2 yang menyatakan variabel "produk (X1) berpengaruh secara parsial terhadap keputusan pembelian pada Toko Buku Karisma Balikpapan” dapat diterima. Berdasarkan fakta yang ada di lapangan, tanggapan responden tentang produk mayoritas menyatakan netral di butir pernyataan pertama, kedua, ketiga, dan keempat. Namun, dari hasil SPSS menunjukkan adanya pengaruh secara signifikan dari variabel produk terhadap keputusan pembelian. Hal ini mengindikasikan bahwa keputusan pembelian konsumen ditunjang oleh indikator yang digunakan dalam variabel produk yaitu, kelengkapan dan keberagaman produk yang ditawarkan, produk-produk yang ditawarkan berkualitas baik, selalu memberikan informasi mengenai produk baru serta adanya jaminan apabila produk tidak berfungsi sebagaimana yang diharapkan, sehingga hal ini perlu dipertahankan dan ditingkatkan bagi Toko Buku Karisma Balikpapan. 
Selanjutnya berdasarkan hasil penelitian untuk variabel harga diperoleh nilai thitung $>$ $t_{\text {tabel }}(3,215>1,98177)$ dan nilai Sig. $(0,002)<0,05$, maka Ho ditolak dan Ha diterima yang berarti $\mathrm{H}_{3}$ yang menyatakan variabel "harga $\left(\mathrm{X}_{2}\right)$ berpengaruh secara parsial terhadap keputusan pembelian pada Toko Buku Karisma Balikpapan” dapat diterima. Berdasarkan fakta yang ada di lapangan, tanggapan responden tentang harga mayoritas menyatakan setuju di butir penyataan pertama, kedua, dan ketiga, tetapi di butir pernyataan keempat mayoritas menyatakan netral. Namun, hasil SPSS menunjukkan adanya pengaruh secara signifikan dari variabel harga terhadap keputusan pembelian. Fakta ini membuktikan bahwa responden menyetujui harga dapat menarik minat responden untuk membeli produk di Toko Buku Karisma Balikpapan. Hal ini mengindikasikan bahwa keputusan pembelian konsumen ditunjang oleh indikator yang digunakan dalam variabel harga yaitu, keterjangkaun harga barang yang ditawarkan, harga barang yang ditawarkan sesuai dengan kualitas produk, harga barang yang ditawarkan bersaing dengan pesaing lain serta adanya potongan harga/diskon yang diberikan, sehingga hal ini perlu dipertahankan dan ditingkatkan bagi Toko Buku Karisma Balikpapan.

Untuk variabel $\mathrm{X}_{3}$ nilai $\mathrm{t}_{\text {hitung }}<\mathrm{t}_{\text {tabel }}(0,518<1,98177)$ dan nilai Sig. $(0,606)>0,05$, maka Ho diterima dan $\mathrm{Ha}$ ditolak yang berarti $\mathrm{H}_{4}$ yang menyatakan variabel "lokasi $\left(\mathrm{X}_{3}\right)$ berpengaruh secara parsial terhadap keputusan pembelian pada Toko Buku Karisma Balikpapan” tidak dapat diterima.Berdasarkan fakta yang ada di lapangan, tanggapan responden tentang lokasi mayoritas menyatakan setuju di butir pernyataan pertama, kedua, ketiga, dan keempat, tetapi di butir pernyataan kelima mayoritas menyatakan netral. Fakta ini membuktikan bahwa responden tidak terlalu memperhatikan lokasi sebagai pertimbangan keputusan pembelian. Hal ini mengindikasikan bahwa indikator yang digunakan dalam variabel lokasi yaitu, lalu lintas kendaraan, fasilitas parkir, transportasi umum, komposisi toko, dan letak berdirinya toko tidak terlalu diperhatikan oleh konsumen dalam melakukan keputusan pembelian, karena konsumen rata-rata telah memiliki kendaraan pribadi yang memungkinkan konsumen dapat berbelanja di Toko Buku Karisma Balikpapan.

Kemudian untuk variabel promosi diperoleh nilai $t_{\text {hitung }}>t_{\text {tabel }}(3,027<1,98177)$ dan nilai Sig. $(0,003)<0,05$, maka Ho ditolak dan $\mathrm{Ha}$ diterima yang berarti $\mathrm{H}_{5}$ yang menyatakan variabel "promosi $\left(\mathrm{X}_{4}\right)$ berpengaruh secara parsial terhadap keputusan pembelian pada Toko Buku Karisma Balikpapan” dapat diterima. Berdasarkan fakta yang 
ada di lapangan, tanggapan responden tentang promosi mayoritas menyatakan setuju di butir pernyataan kedua dan mayoritas menyatakan netral di butir pernyataan pertama, ketiga, dan keempat. Namun, dari hasil SPSS menunjukkan adanya pengaruh secara signifikan dari variabel promosi terhadap keputusan pembelian. Hal ini menunjukkan bahwa promosi yang dilakukan oleh pihak Toko Buku Karisma Balikpapan sudah cukup baik, seperti Toko Buku Karisma menjalin hubungan komunikasi dengan konsumen, dan juga menyediakan layanan pusat informasi yang siap membantu. Konsumen yang memiliki informasi yang cukup tentang Toko Buku Karisma Balikpapan akan mempertimbangkan untuk melakukan pembelian terhadap produk yang di sediakan oleh Toko Buku Karisma Balikpapan. Dalam hal ini promosi sangat berguna untuk menginformasikan, mempengaruhi dan membujuk konsumen untuk menarik minat konsumen dalam melakukan pembelian pada Toko Buku Karisma Balikpapan.

\section{PENUTUP}

Disarankan agar kualitas produk yang disediakan oleh pihak Toko Buku Karisma Balikpapan lebih ditingkatkan lagi dari segi kelengkapan dan keberagaman produk, desain dan fitur produk agar lebih menarik lagi serta produk yang disediakan lebih ditingkatkan lagi kualitasnya. Toko Buku Karisma juga dapat menetapkan harga yang kompetitif agar tidak kalah bersaing dengan pesaing lain guna menarik perhatian lebih banyak konsumen dari sebelumnya.

Kemudian disarankan Toko Buku Karisma Balikpapan memerhatikan kembali dan melakukan perubahan tampilan depan dan papan nama toko didekor semenarik mungkin, sehingga lebih mudah terlihat dan menarik perhatian para konsumen, menata ulang dan merapikan tata letak produk, sehingga konsumen tidak kesulitan mencari produk yang dibutuhkan, aroma dan musik sangat dibutuhkan, karena membuat konsumen merasa nyaman, pelayanan toko juga harus ditingkatkan agar membuat konsumen merasa puas dan memutuskan untuk melakukan pembelian. Untuk penerapan promosi yang dilakukan selanjutnya semakin ditingkatkan guna menarik perhatian lebih banyak konsumen dari sebelumnya.

Terkahir, diharapkan hasil penelitian ini dapat dijadikan referensi untuk penelitian mendatang guna memperoleh hasil penelitian yang lebih luas lagi, maka disarankan untuk menambah variabel lain yang tidak diteliti dalam penelitian ini untuk mengetahui apakah variabel lain tersebut berpengaruh secara signifikan atau tidak terhadap keputusan pembelian. 


\section{DAFTAR PUSTAKA}

Abdullah, Thamrin dan Francis Tantri. 2015. Manajemen Pemasaran. Cetakan ke-4. PT Raja Grafindo Persada. Jakarta.

Adam, Muhammad. 2015. Manajemen Pemasaran Jasa. Cetakan Kesatu. Alfabeta. Bandung.

Alma, Buchari. 2013. Manajemen Pemasaran dan Pemasaran Jasa. Cetakan Kesepuluh. Alfabeta. Bandung.

Assauri, Sofjan. 2014. Manajemen Pemasaran. Cetakan ke-13. PT Raja Grafindo Persada. Jakarta.

Harianto, Rudy Pudjut. 2017. Paduan Praktis SPSS Untuk Penelitian. Cetakan Pertama. Heart \& Soul Media Aksara. Balikpapan.

Hasan, Ali. 2008. Marketing. Cetakan ke-1. CAPS. Yogyakarta.

Hasan, Ali. 2014. Marketing dan Kasus-Kasus Pilihan. Cetakan ke-2. CAPS. Yogyakarta.

Kotler, Philip dan Kevin L. Keller. 2008. Manajemen Pemasaran. Edisi 12. Jilid 1. Erlangga. Jakarta.

Maharani, Esthi. 2017. IKAPI: Penjualan Buku Menurun. https://www.republika.co.id/berita/pendidikan/eduaction/17/04/25/ooy9ig335-ikapipenjualan-buku-menurun. 18 November 2019. ( 13.23 ).

Malasari, Dewi. 2017. Pengaruh Harga, Produk, Promosi, dan Lokasi terhadap Keputusan Pembelian Konsumen pada Toko Alimudin. Skripsi. Sekolah Tinggi Ilmu Ekonomi Madani (STIE Madani). Balikpapan.

Marendra, I Gede. 2018. Pengaruh Bauran Pemasaran (Produk, Harga, Lokasi, dan Promosi) terhadap Keputusan Pembelian Konsumen di Minimarket (Alfamart Atau Indomaret). Jurnal Pemasaran Kompetitif 1 (3): 34-52.

Mawahib, M Jauharul. 2015. Pengaruh Bauran Pemasaran terhadap Keputusan Pembelian Smartphone Samsung (Studi Kasus pada Mahasiswa Adminitrasi Bisnis Universitas Mulawarman). eJournal Administrasi Bisnis 3 (4): 858-872.

Prasetya, Tjoa, Billy Jana. 2015. Pengaruh Bauran Pemasaran (Retailing Mix) terhadap Keputusan Pembelian Konsumen pada Toko Jana Abadi. Skripsi. Sekolah Tinggi Ilmu Ekonomi Madani (STIE Madani). Balikpapan.

Qerja.com. 2019. Profil Karisma Aksara Mediatama PT. https://www.qerja.com/company/view/karisma-aksara-mediatama-pt. 29 November 2019. (20.13).

Sangadji, Etta Mamang dan Sopiah. 2013. Perilaku Konsumen. CV Andi. Yogyakarta.

Sudaryono. 2016. Manajemen Pemasaran Teori \& Implementasi. CV Andi. Yogyakarta. 
Suharno dan Yudi Sutarso. 2010. Marketingi in Practice. Cetakan ke-1. Graha Ilmu. Yogyakarta.

Sugiyono. 2014. Metode Penelitian Bisnis. Cetakan ke-18. Alfabeta. Bandung.

Sugiyono. 2015. Metode Penelitian Kuantitatif, Kualitatif, dan $R \&$ D. Cetakan ke-22. Alfabeta. Bandung.

2016. Metode Penelitian Kuantitatif, Kualitatif, dan $R$ \& D. cetakan ke-23. Alfabeta. Bandung.

Susanti, Heni, Maskuri Sutomo, dan Benyamin Parubak. 2017. Pengaruh Bauran Pemasaran terhadap Keputusan Pembelian Smartphone Merek Samsung pada Mahasiswa Universitas Alkhairaat Palu. Jurnal Ilmu Manajemen Universitas Tadulako 3 (3): 279288.

Suyonto, Danang. 2014. Dasar-dasar Manajemen Pemasaran (Konsep, Strategi, dan Kasus). Cetakan Ketiga. CAPS. Yogyakarta.

Sunyoto, Danang. 2014. Konsep Dasar Riset Pemasaran dan Perilaku Konsumen. Cetakan Kedua. CAPS. Yogyakarta.

Sunyoto, Danang. 2015. Perilaku Konsumen dan Pemasaran. Cetakan Pertama. CAPS. Yogyakarta.

Tjiptono, Fandy. 2015. Strategi Pemasaran. Edisi 4. Penerbit ANDI. Yogyakarta.

TokoKarisma.com. 2017. Tentang PT Karisma Aksara. http://tokokarisma.com/index.php? route=information/information/agree\&information_i $\underline{d=4} .18$ November 2019. ( 13.50 ).

Umar, Husein. 2013. Metode Penelitian untuk Skripsi dan Tesis Bisnis. Cetakan ke-12. PT Raja Grafindo Persada. Jakarta.

Wahid, Nur. 2017. Pengaruh Bauran Pemasaran terhadap Keputusan Pembelian Produk Merek Celcius di Jalan Gatot Subroto Samarinda. eJournal Administrasi Bisnis 5 (2): 401-413.

Walukow, A. L. Pratisitia, Lisbeth Mananeke, dan Jantje Sepang. 2014. Pengaruh Kualitas Produk, Harga, Promosi, dan Lokasi terhadap Keputusan Pembelian Konsumen di Bentenan Center Sonder Minahasa. Jurnal EMBA 2 (3): 1737-1749. 